PLURAL, Revista do Programa de Pós-Graduação em Sociologia da USP, São Paulo, v. 16, n. 1, pp. 175-188, 2009

\title{
Por uma Sociologia do Conhecimento Científico da Questão Ambiental - A Produção Acadêmica Brasileira sobre Desenvolvimento Sustentável e Sustentabilidade: Resultados Preliminares
}

\author{
Victor Kanashiro*
}

\begin{abstract}
Resumo: A sustentabilidade tem sido apresentada como um dos grandes desafios da sociedade contemporânea. Consolidada como uma das prioridades na agenda política internacional e presente nos discursos de chefes de Estado, organismos internacionais, ONGs, empresas e movimentos sociais, a temática do desenvolvimento sustentável e sustentabilidade vem sendo investigada e discutida no campo acadêmico com diferentes abordagens teóricas e tradiçóes disciplinares, pelo menos desde a publicação do Relatório Brundtland, em 1987. Tendo isso em vista, este artigo problematiza a temática do desenvolvimento sustentável e sustentabilidade, procurando argumentar acerca da necessidade de uma Sociologia do Conhecimento Científico sobre a questão ambiental, no contexto da modernidade radicalizada e apresentando os principais resultados parciais da pesquisa em andamento: "Uma sociologia do conhecimento da questão ambiental: a produção acadêmica brasileira sobre desenvolvimento sustentável e sustentabilidade".

Palavras-chave: desenvolvimento sustentável; sociologia do conhecimento; interdisciplinaridade.
\end{abstract}

\section{A Sociology of Knowledge of Environmental Issues: Brazilian Academic Production on Sustainable Development and Sustainability}

Abstract: Sustainability has been presented as one of the most important challenges in contemporary society. Established as a priority in international political agenda and present in the speeches of heads of States, international organizations, NGOs, companies and social movements, sustainable development and sustainability issues have also been investigated and discussed in academic field through different theoretical approaches and disciplinary traditions, at least since the publication of Brundtland Report in 1987. Based on this, this article discusses

\footnotetext{
* Victor Kanashiro é mestrando no Programa de Pós-Graduação em Sociologia da Unicamp, bacharel em Ciências Sociais pela PUC-SP e em Ciências Econômicas pela FEA-USP.
} 
the Brazilian academical production on sustainable development and sustainability, contending for the need of a sociology of scientific knowledge of environmental issues in radicalized modernity and presenting the main preliminary results of the research in process: "A sociology of knowledge of environmental issues: brazilian academic production on sustainable development and sustainability". Keywords: sustainable development; sociology of knowledge; interdisciplinarity.

\section{INTRODUÇÃO}

Desde a emergência dos movimentos ambientalistas na década de 1960, a questão ambiental vem se estabelecendo como tema fundamental para a compreensão da sociedade contemporânea, seus conflitos e contradiçóes. A alarmante percepçáo da degradaçáo e mudanças ambientais tem provocado debates polêmicos que envolvem ativistas, chefes de governo e cientistas de diversas áreas do saber. Questionamentos sobre os limites e consequências ambientais do crescimento econômico, os impactos sociais da degradaçáo ambiental, a possibilidade do desenvolvimento aliado à sustentabilidade e, mais recentemente, as causas e consequências do aquecimento global têm sido apresentados e debatidos em eventos como o controverso estudo Limits to Growth, preparado para o Clube de Roma em 1972, a Conferência de Estocolmo no mesmo ano, o Relatório Brundtland em 1987, a Conferência das Naçôes Unidas para o Meio Ambiente e o Desenvolvimento em 1992, entre outros.

Nesse contexto, a questáo ambiental passou a ocupar um lugar privilegiado na agenda e no discurso de organizaçôes internacionais, Estado-naçôes, empresas, partidos políticos, ONGs e movimentos sociais. Também cientistas e intelectuais - de biólogos a cientistas sociais passaram a incluir a questão como objeto de pesquisa, e, desde então, a produção científica sobre o tema tem aumentado significativamente.

É assim que, na questăo ambiental, diversas ciências e abordagens teóricas têm confluído em torno de uma questáo política essencial: a disputa e a cooperação dos diferentes atores sociais em torno da preservação e sustentação dos processos vitais, buscando inclusão e justiça social e respeito à diversidade cultural. Entretanto, essa confluência e essa abrangência, inerentes à própria questâo ambiental, configuram simultaneamente sua força e importância, bem como seus limites. Se, por um lado, ela traz em seu interior a discussão política quanto à forma de sociedade, suas práticas e seus valores, por outro, a multiplicidade de concepçóes e de interesses representados e camuflados pelas diferentes orientaçóes teóricas e políticas na discussão ambiental ameaça precipitar o debate em um diálogo no qual diferenças irreconciliáveis estão ocultas sob um mesmo termo: meio ambiente (DryseK, 2005; HoEfFel, 2009).

Por isso, neste artigo, pretende-se refletir sobre uma Sociologia do Conhecimento Científico da questão ambiental que possibilite visualizar as distintas "visôes de mundo" (ManNHeIM, I968), "paradigmas disciplinares" (KuHN, 2007) e interesses que norteiam e condicionam a produção intelectual do campo científico em torno da questáo ambiental. Especificamente, foca-se na problematizaçáo e nos resultados parciais da pesquisa de mestrado "Uma sociologia do conheci- 
mento da questão ambiental: a produção acadêmica brasileira sobre desenvolvimento sustentável e sustentabilidade $\mathrm{I}^{\mathrm{l}}$, cujo intuito é investigar os condicionantes sociais e "ideológicos"² da produção acadêmica brasileira sobre a temática do desenvolvimento sustentável e sustentabilidade, procurando mapear as distintas abordagens existentes e buscar as origens das divergências sobre o tema.

\section{SOCIOLOGIA DO CONHECIMENTO CIENTÍFICO E A QUESTÃO AMBIENTAL}

Entretanto, antes de apresentar os resultados preliminares da referida pesquisa, é necessário realizar uma breve reflexão em torno de por que fazer uma Sociologia do Conhecimento Científico da questão ambiental. Como se sabe, a Sociologia do Conhecimento Científico é o subcampo da Sociologia que passou a entender os conteúdos da ciência como passíveis de análise sociológica. Se, por um lado, foi fortemente influenciada pela Sociologia do Conhecimento mannheimniana, deve grande parte de seu desenvolvimento à crítica à Sociologia da Ciência mertoniana, viabilizada, sobretudo, pela emergência de uma visão historicamente orientada na filosofia da ciência, tal qual a de Kuhn e Feyerabend.

Se a Sociologia da Ciência de Robert Merton permitiu identificar um ethos científico orientador de práticas características do cientista - ainda que sem romper com uma visão standart ${ }^{3}$ da ciência -, a Sociologia do Conhecimento Científico está vinculada ao questionamento dos próprios conteúdos da ciência, enquanto objetos de problematização sociológica.

Como exemplo, pode-se citar o trabalho precursor de David Bloor (1976), um dos expoentes do Programa Forte da Escola de Edimburgo, que procurou demonstrar que a objetividade da Matemática pode ser estudada sociologicamente, uma vez que é construída por meio de convenções e negociaçóes em torno de padróes e provas.

Nesse sentido, levando-se em consideração - na linha de uma Sociologia mannheimniana - que o pensamento e o conhecimento estão condicionados historicamente, existencialmente e socialmente, o próprio desenvolvimento da Sociologia do Conhecimento Científico, assim como o de uma Sociologia Ambiental, pode ser entendido dentro de um contexto macrossocial da sociedade contemporânea.

No que tange à qualificação desse contexto, sem poder se aprofundar em uma análise mais detalhada, pode-se dizer que a instituiçáo científica e seus produtos sociais constituem elementos fundamentais em sua configuração e suas transformaçôes (CASTORIADIs, I997).

I Pesquisa em desenvolvimento pelo autor deste artigo no Programa de Pós-graduação em Sociologia da Unicamp, sob orientaçáo da Profa. Dra. Leila da Costa Ferreira e financiada pela Fapesp (Processo: 2008/51629-8).

2 Utiliza-se o termo em sua concepção total, como elaborada por Mannheim (op. cit.).

3 Para Mulkay (1985), a visão standart da ciência pode ser caracterizada pelos seguintes pontos: o mundo natural é visto como real e objetivo; a ciência é o empreendimento intelectual que fornece a explicaçáo mais precisa dos objetos, processos e relaçóes que ocorrem no mundo natural; apesar das mudanças e movimentos contínuos no mundo natural, há regularidades empíricas que podem ser expressas em leis universais e permanentes da natureza; a validade do conhecimento científico pode ser garantida porque a ciência desenvolveu critérios rigorosos de experimentos procedimentais que garantem a independência de fatores subjetivos. 
O desenvolvimento industrial, os avanços das tecnologias de informação e comunicação e a centralidade que ganha o conhecimento científico nos processos de tomada de decisão são indícios de que o desenvolvimento da ciência, em sua ambição iluminista, mostra-se parte constitutiva dessa modernidade contemporânea. No entanto, ao mesmo tempo em que avanços materiais inegáveis dessa modernidade se expandem globalmente, muitos são os problemas e conflitos sociais gerados nesse processo. Eventos como o desenvolvimento de armas nucleares e a crise ecológica anunciada são indícios de que a modernidade ou pelo menos a ambição dos ideais modernos chegaram a um estágio em que ela se depara com suas próprias consequências e contradiçóes.

Nesse contexto, enquanto alguns autores falam de uma condição pós-moderna (LYOTARD, 1986) ou de uma incompletude do projeto moderno (HABERMAS, I992), outros preferem qualificar as transformaçōes da sociedade contemporânea como uma radicalização da modernidade, em que algumas de suas principais características passam a ser seu caráter reflexivo e a centralidade dos riscos na organizaçấo social (Giddens, I99I; BeCK, I992).

Na concepção de Giddens (op. cit.), a reflexividade da vida social moderna consiste no fato de que as práticas sociais são constantemente examinadas e reformuladas à luz da informaçáo renovada sobre essas próprias práticas. Dessa forma, ainda que náo de forma direta e linear, o próprio desenvolvimento da ciência e tecnologia pode ser visto como produtor das condiçóes para a emergência de reflexôes em torno da própria natureza da reflexão e do conhecimento científico. É nesse sentido que se pode entender a Sociologia do Conhecimento Científico como, de um lado, produto da radicalizaçáo da modernidade e, por outro, uma prática reflexiva da própria produção do conhecimento científico.

Como indica Giddens (op. cit.), somente no final do século XX é que se pôde perceber quâo perturbadora é a perspectiva da modernizaçáo reflexiva, já que, quando as reivindicaçóes da razão substituíram as da tradição, elas pareciam oferecer uma sensação de certeza maior do que a que era propiciada pelo dogma anterior. Mas, como ele próprio argumenta, a equação entre conhecimento e certeza revelou-se erroneamente interpretada:

Estamos em grande parte num mundo que é inteiramente constituído através do conhecimento reflexivamente aplicado, mas onde, ao mesmo tempo, não podemos nunca estar seguros de que qualquer elemento dado deste conhecimento não seja revisado (Giddens, op. cit., p. 40).

Pensando especificamente na questão ambiental, temas como o aquecimento global ou a sustentabilidade do desenvolvimento parecem receber cada vez mais atenção da comunidade científica, ao mesmo tempo em que se multiplicam as incertezas e controvérsias em torno deles, isto é, a reflexividade da modernidade radicalizada parece estar visível em dois sentidos nesse caso. Em primeiro lugar, a reflexão em torno da questão ambiental evidencia os processos pelos quais a modernidade passa a se deparar com as consequências da própria modernizaçáo da sociedade - 0 que inclui a supervalorização e centralidade da ciência e tecnologia nos processos de tomada de 
decisão e na organização da vida social. Em segundo lugar, o próprio questionamento da ciência e tecnologia enquanto promotores incondicionais da verdade objetiva e do progresso permitiu a emergência de um pensamento reflexivo sobre o conhecimento científico.

Nessa perspectiva, existem pelo menos três argumentos na defesa de uma Sociologia do Conhecimento Científico da questão ambiental. Em primeiro lugar, ela parece ser um instrumento de análise bastante frutífero para se compreender aspectos da "dominaçáo" do homem sobre a natureza na modernidade radicalizada, uma vez que permite observar as relaçóes entre a produçáo do conhecimento científico sobre a natureza, suas origens e consequências socioambientais.

Em segundo lugar, abordagens construcionistas da Sociologia Ambiental (Hannigan, 2009) indicam que grande parte dos problemas e riscos ambientais são mediados pelo diagnóstico e pelo conhecimento científico, muitas vezes, controversos (YearLeY, 1992). Portanto, o papel do cientista e de experts na definiçáo e resoluçáo de problemas ambientais é central.

Em terceiro lugar, com a emergência do entendimento de que a questâo ambiental não poderia ser compreendida apenas em seus aspectos físicos ou sociais, passaram a se formar programas de pesquisa e campos acadêmicos altamente interdisciplinares em torno dela, reunindo diversos paradigmas disciplinares e visôes de mundo distintos em espaços institucionais e intelectuais comuns.

Nesse sentido, uma análise de espaços como esse poderia explicitar o confronto do que Bourdieu (200I) chamou de habitus disciplinar e que toma formas específicas segundo as especialidades. Para ele, o contato entre as ciências é uma ocasiáo oportuna para perceber as diferenças entre os distintos sistemas de disposição que estâo no princípio das práticas científicas.

Com isso em vista, pode-se dizer que uma Sociologia do Conhecimento Científico da questáo ambiental permite investigar as origens de divergências teóricas em torno de temas comuns a várias tradiçóes disciplinares, náo apenas vinculadas a interesses específicos ou problemas de consistência lógica de um arcabouço teórico, mas também aos condicionantes sociais e "ideológicos" do pensamento científico.

A questáo ambiental pode, nesse sentido, evidenciar a disputa teórica e política em torno da definição de certas ideias e conceitos. Nessa linha, se a internalização da questáo ambiental no campo científico colocou em pauta a temática da interdisciplinaridade, ela passou também, assim como a nova Sociologia do Conhecimento, a questionar as fronteiras entre as ciênciais sociais e naturais, entre a ciência e a política.

Por fim, por sua construção política como tema de interesse global, a produçấo científica sobre a questão ambiental recoloca a problemática da posição social do cientista na produção do conhecimento. Isso porque, certamente, contextos sociais e institucionais distintos podem gerar temas, abordagens e conclusóes distintas. 


\section{A PRODUÇÃO ACADÊMICA BRASILEIRA SOBRE SUSTENTABILIDADE E DESENVOLVIMENTO SUSTENTÁVEL: RESULTADOS PRELIMINARES}

Uma análise da discussão sobre desenvolvimento sustentável e sustentabilidade parece ser emblemática para evidenciar como diferentes paradigmas disciplinares podem orientar sentidos diferentes para um mesmo termo. Desde sua origem, no bojo das discussóes sobre a incompatibilidade entre crescimento econômico e preservação ambiental características da década de 1970, a força da noçáo de desenvolvimento sustentável esteve na produção de algum consenso. No entanto, sua amplitude e imprecisão dão margem às mais diversas interpretaçôes, definiçốes e ao uso.

Para Nobre (2002), são justamente as fraquezas, imprecisōes e contradiçóes da noçáo de desenvolvimento sustentável as razóes da aceitaçáo geral que frequentemente a envolve. Isto é, a noção se tornou pervasiva, porque conseguiu reunir em si posiçóes teóricas e políticas contraditórias e até mesmo opostas. Analisando seu processo de institucionalizaçáo, Nobre (op. cit.) afirma que isso ocorre porque a noçáo de desenvolvimento sustentável náo nasceu definida, ou seja, sua conceituação e seu sentido são decididos no debate teórico e na luta política.

Segundo Ferreira (2006), do ponto de vista histórico, o termo sustentabilidade foi cunhado com o propósito de remeter ao vocábulo sustentar'; sustentar algo, ao longo do tempo, para que aquilo que se sustenta tenha condiçóes de permanecer perene, reconhecível e cumprindo as mesmas funçôes indefinidamente, sem que produza qualquer tipo de reação desconhecida, mantendo-se estável ao longo do tempo.

Entre os inúmeros conceitos de sustentabilidade (incluindo seus derivados, como desenvolvimento sustentável) elaborados nos últimos anos, o que se pretende - e sobre isso parece haver consenso - é encontrar os mecanismos de interação entre as sociedades humanas que ocorram em uma relação harmoniosa com a natureza. Dessa forma, Nobre (op. cit.) acredita que o debate esteja vinculado, em última instância, às diferentes visóes de como se deva dar a institucionalizaçâo da problemática ambiental.

Por conta dessas características, a literatura sobre o desenvolvimento sustentável tem se dividido entre as tarefas de apresentar uma definiçáo mais adequada e mais abrangente do que todas as outras tentativas anteriores e a de buscar catalogar as imprecisóes e contradiçóes das diversas definiçóes apresentadas (NoBRE, op. cit.).

Com isso em vista, a pesquisa de mestrado "Uma sociologia do conhecimento da questáo ambiental: a produção acadêmica brasileira sobre desenvolvimento sustentável e sustentabilidade" procura problematizar a literatura acadêmica brasileira sobre o tema, menos com o intuito de

\footnotetext{
4 Para Paehlke (I989) e Ferreira (2006), o termo sustentabilidade foi cunhado em I7I3 pelo silvicultor e minerador saxão Hans Carl Carlowitz, visando a um uso do solo cultivável que garantisse rendimentos estáveis a longo prazo na produçáo florestal. Em sua obra Sylvicultura Oeconomica, Carlowitz criticava a visão de curto prazo dos administradores florestais, argumentando que os lucros com o corte de madeira deveriam ser contrapostos ao fato de que lucros provenientes de geraçóes futuras de árvores só poderiam acontecer após um longo tempo. Nesse sentido, acreditava que se deveria ter uma exploração mais cautelosa de madeira, garantindo um equilíbrio entre o crescimento das árvores e o corte de madeira (EDINGER \& KAUL, 2003).
} 
buscar a melhor definição para o termo e mais com o de investigar as origens das divergências das diferentes abordagens sobre desenvolvimento sustentável e sustentabilidade.

Os resultados preliminares dessa pesquisa e do projeto temáticos "A questão ambiental, interdisciplinaridade, teoria social e produçáo intelectual na América Latina", ao qual está vinculada, mostram que há uma produção crescente de diversas disciplinas científicas de todas as áreas do conhecimento, em torno da questâo ambiental, tanto no Brasil quanto na América Latina, e evidenciam algumas especificidades dessa literatura.

Para Ferreira (2009), coordenadora do projeto temático em questáo, há certa expectativa de que cientistas latino-americanos dediquem a maior parte de sua energia na investigaçáo de problemas e questôes relacionados com as áreas naturais, rigorosamente falando, já que o subcontinente tem sido imaginado como uma espécie de "paraíso natural", violado e contaminado, depois de séculos de influência ocidental indesejada.

Isso não quer dizer, porém, que não existam problemas e preocupaçôes que, se não únicos, são mais caros aos países latino-americanos do que a outras comunidades científicas e seus decisores políticos. Nesse sentido, é absolutamente compreensível que temas como desigualdade social, biodiversidade e democracia façam frequentemente parte das investigaçóes consideradas na pesquisa. E, ainda que isso não seja suficiente para conduzir a comunidade científica latinoamericana para uma situaçáo de excepcionalidade no cenário mais amplo do mundo científico, pode-se perceber que, como no "primeiro mundo", há, na América Latina, uma agenda de pesquisa própria, que reflete e reverbera temas e problemas que tanto a comunidade científica quanto a sociedade da qual esta faz parte pensam ser relevantes.

A pesquisa foi realizada com auxílio do Banco de Dados Latino-Americano em Ambiente e Sociedade (Lamas), desenvolvido no âmbito do projeto temático em questáo, e permitiu um mapeamento temático interdisciplinar e quantitativo da produção intelectual latino-americana sobre questão ambiental.

No caso específico da literatura acadêmica brasileira sobre a questáo do desenvolvimento sustentável e sustentabilidade, até outubro de 2009 puderam ser identificados $478 \operatorname{livros}^{6}$, publicados por autores brasileiros das mais diversas áreas do conhecimento, sobre o tema, desde 1987, quando foi lançado o Relatório Brundland.

O Gráfico I mostra uma tendência de crescimento, no período estudado, da publicaçáo de livros sobre desenvolvimento sustentável e sustentabilidade. Deve-se notar que a baixa incidência nos anos de 2008 e 2009 provavelmente decorra do tempo de defasagem entre a publicação e a compra das obras pelas bibliotecas nas quais foi feito o levantamento.

5 Projeto financiado pela Fapesp (Processo: 05/52317-I), coordenado por Leila da Costa Ferreira, professora titular do Departamento de Sociologia do Ifch/Unicamp.

6 Levantamento realizado na rede de bibliotecas da USP (Dedalus), Unicamp (Sophia) e Unesp (Athena), por meio das palavras-chave "desenvolvimento sustentável", "sustentabilidade" e "ecodesenvolvimento" nos campos "título" e "palavra-chave", no dia 30 de outubro de 2009. 


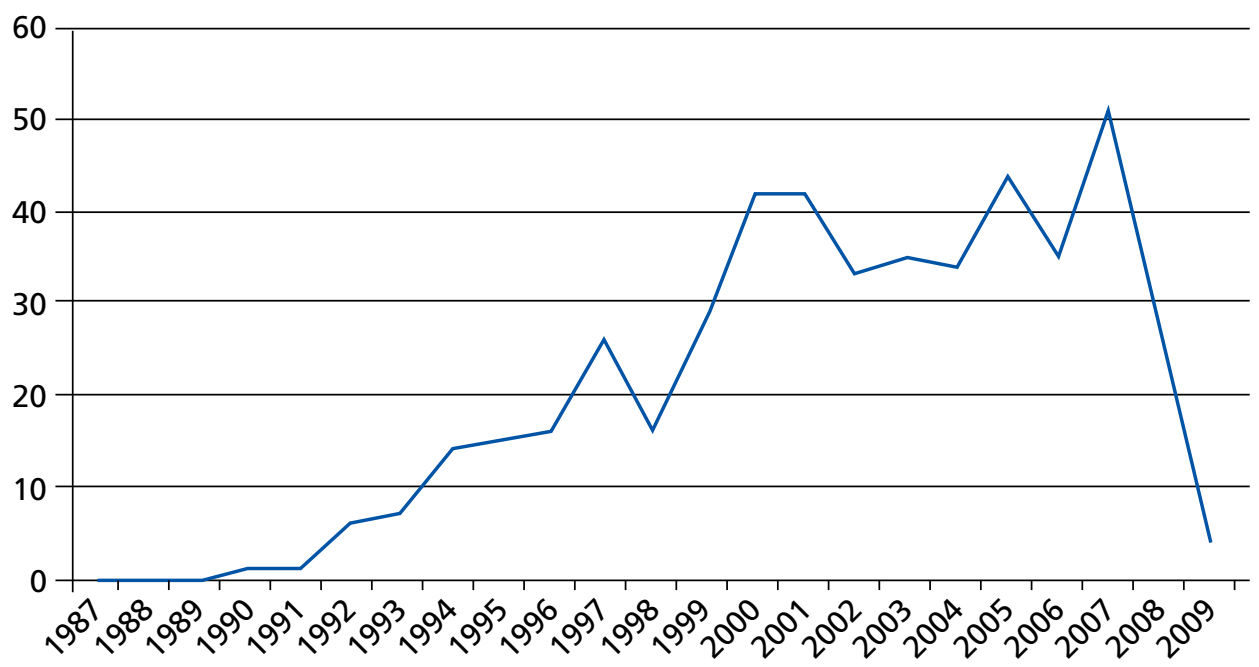

Número de livros por ano de publicação

Gráfico I. Número de livros por ano de publicação (1987-out./2009).

No que se refere a artigos, tomando como universo empírico apenas as revistas qualis AI, A2, BI, B2 da base Scielo Brasil, até outubro de 2009, foram identificados I8I artigos ${ }^{7}$, distribuídos em 55 períodicos (cerca de $25 \%$ de toda a base). Desse total, $42 \%$ foi publicado em revistas consideradas $^{8}$ de ciências sociais, $27 \%$, em ciências agrárias, $13 \%$, em ciências exatas e engenharias, IO\%, em ciências sociais aplicadas, 7\%, em ciências da saúde, I\%, em ciências biológicas.

Esses dados mostram uma preponderância relativa na quantidade de artigos publicados em revistas classificadas como de ciências sociais, mas também uma produção relevante em todas as áreas do conhecimento, evidenciando o caráter multidisciplinar e interdisciplinar da produção acadêmica sobre a temática do desenvolvimento sustentável e da sustentabilidade no Brasil.

Além disso, na base empírica de artigos, é possível constatar que 75,6\% dos artigos foram produzidos em coautoria. $\mathrm{O}$ índice de coautoria ${ }^{9}$ é de $87 \%$ em ciências agrárias, $72 \%$ em engenharias e $69 \%$ em ciênciais sociais, bem maior que os $36 \%$ registrados, se considerados todos os artigos de ciências sociais da base Scielo.

7 Resultado da busca realizada na base Scielo Brasil, simultaneamente, com as palavras-chave "sustentabilidade", "desenvolvimento sustentável" e "ecodesenvolvimento", no dia 30 de outubro de 2009.

8 Foram tomados como referência os critérios da própria base Scielo na classificação dos periódicos por área do conhecimento.

9 Índice de coautoria = quantitade de artigos em coautoria da área/quantidade total da área. 


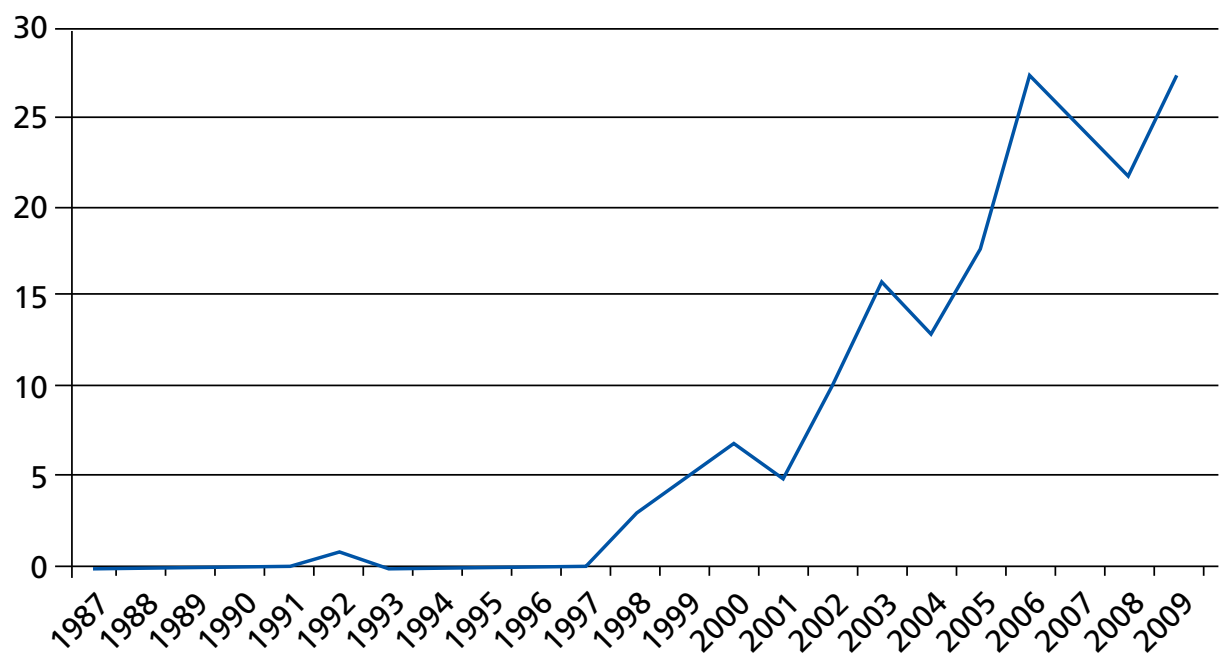

Artigos por ano de publicação

Gráfico 2. Artigos por ano de publicação (1987-out./2009).

Esses dados podem indicar uma prática científica diferenciada na produção do conhecimento sobre a questão ambiental, especialmente nas ciênciais sociais, em que tradicionalmente a prática da coautoria é menos comum que em outras áreas do conhecimento.

O Gráfico 2, que relaciona a quantidade de artigos sobre desenvolvimento sustentável e sustentabilidade por ano de publicação, assim como o Gráfico I, sobre livros, mostra uma tendência de crescimento da produçáo de artigos sobre o tema no período estudado. Deve-se salientar que a baixa incidência entre 1987 e 1997 provavelmente decorra de um viés da própria base Scielo Brasil, que mantém uma amostra de artigos publicados somente a partir de 1997.

Mesmo assim, os gráficos I e 2 permitem identificar uma quantidade cada vez maior de livros e artigos publicados nos últimos vinte anos no Brasil, evidenciando que, de fato, a discussáo em torno da temática em questão, ainda que tenha emergido no âmbito da política - como sugerem Nobre e Amazonas (2002) -, foi amplamente internalizada como tema das diversas ciências da academia brasileira. Também por isso, fica evidente a necessidade de se fazer um mapeamento e a análise qualitativa dessa literatura, a fim de compreender, para além de um mapeamento quantitativo, o que se tem dito sobre a questão.

Por isso, em uma segunda fase da pesquisa em andamento, serão selecionadas amostras tanto na base empírica de artigos quanto de livros, a fim de se realizar uma análise qualitativa da literatura levantada e se identificar concepçóes expressivas sobre desenvolvimento sustentável e sustentabilidade presentes na literatura acadêmica brasileira. 
A seguir, são apresentadas algumas revisōes anteriores já realizadas, na tentativa de se qualificar as diferentes abordagens da questâo da sustentabilidade. Certamente, elas serão de grande valia na identificaçấo de concepçôes expressivas do desenvolvimento sustentável e sustentabilidade proposta nessa investigação.

Lima (2003) apresenta duas grandes matrizes interpretativas que polarizam o debate atual e pretendem abarcar a multiplicidade de enfoques que envolvem a noçáo de sustentabilidade. De um lado, tem-se o discurso oficial, que compreende o desdobramento da proposta da Comissão Brundtland (CMMAD, 1988). Para o autor, trata-se de um discurso pragmático que enfatiza a dimensão tecnológica e econômica da sustentabilidade e que defende a possibilidade de articular crescimento econômico e preservaçáo ambiental.

Nessa abordagem, o processo de transição para o desenvolvimento sustentável será liderado pela economia de mercado, por meio da geraçáo de tecnologias limpas, do controle do crescimento populacional e pela emergência de processos produtivos e de consumo ecologicamente equilibrados.

Esse tipo de entendimento pode ser considerado também como bastante alinhado com a ideia de modernizaçáo ecológica - conceito que descreve e prega a reforma ecológica e novos papéis para a economia de mercado e a intervenção estatal.

Para alguns críticos, trata-se de uma visão relativa a um paradigma da adequaçáo (ACSERALD, 2004), que se insere em uma ideologia desenvolvimentista, segundo a qual os danos ambientais devem ser percebidos como externalidades de mercado, e as paisagens devem ser modificadas e adaptadas aos objetivos de projetos técnicos (Zhouri, Laschefski \& Pereira, 2005).

A outra matriz apresenta-se como uma proposta multidimensional de sustentabilidade que procura integrar dimensóes sociais e individuais. Nessa concepção, segundo Lima (2003), prefere-se utilizar a expressão sociedade sustentável, salientando a autonomia política, a diversidade cultural e os valores éticos de respeito à vida.

Na definiçẫo de Diegues (I992, p. 28):

O conceito de "sociedades sustentáveis" parece ser mais adequado que o de "desenvolvimento sustentável", na medida em que possibilita a cada uma das sociedades definir seus padrôes de produçáo e consumo, bem como o de bem-estar a partir de sua cultura, de seu desenvolvimento histórico e de seu ambiente natural.

Outra maneira de se interpretarem as matrizes é aquela proposta por Veiga (2005), que identifica pelo menos três padrôes de entendimento da sustentabilidade. Em primeiro lugar, aponta o autor, estáo os que acreditam que não existe dilema entre crescimento econômico e preservação do meio ambiente, e que, portanto, a questáo da sustentabilidade náo é relevante.

Esse tipo visão está fundamentada no ultraotimismo de economistas neoclássicos, como o Prêmio Nobel de Economia Robert Solow, para quem, a longo prazo, os ecossistemas não 
oferecerão qualquer tipo de limite, já que, no caso de os recursos naturais se esgotarem, poderse-á substituí-los por outros fatores de produção, como trabalho e tecnologia ${ }^{\text {10 }}$.

Outro argumento muito utilizado nesse tipo de pensamento é aquele com base na curva de Kuznets ambiental ${ }^{\text {II }}$, segundo a qual o crescimento econômico só prejudicaria o meio ambiente até determinado patamar de riqueza, a partir do qual incrementos na renda gerariam demanda por qualidade ambiental, e, portanto, a degradação tenderia a diminuir.

O segundo padrão de resposta identificado por Veiga (op. cit.) é aquele fundamentado nas ideias do economista romeno Nicholas Georgescu-Roegen, caracterizando uma perspectiva essencialmente pessimista. Esse pensador introduz o conceito de entropia na análise econômica, desconstruindo alguns pressupostos da teoria econômica neoclássica e evidenciando a insustentabilidade físico-ambiental do crescimento econômico.

Entendendo os processos econômicos como processos entrópicos, Georgescu-Roegen (1976) chega a uma conclusão bastante incômoda e inconveniente, sobretudo para os otimistas do crescimento: a entropia dos processos consiste em um fenômeno inexorável, implicando que o crescimento econômico material necessariamente depreda sua base física e, portanto, náo pode ser mantido sustentavelmente.

Para Georgescu-Roegen, o máximo que se pode fazer é retardar esse esgotamento com uma utilizaçáo racional dos recursos (NoBre, op. cit.). Nessa linha, um dia a humanidade teria que encontrar uma via de desenvolvimento humano que fosse compatível com a retração, isto é, com o decrescimento do produto (VEIGA, op. cit.).

Para Veiga (op. cit.), a terceira resposta procura abrir um "caminho do meio" entre essas duas teses extremistas. $\mathrm{O}$ autor indica alguns esforços relevantes nesse sentido, como aquele do economista Ignacy Sachs, que, desde a Conferência de Estocolmo (1972), tem evitado, simultaneamente, o ambientalismo pueril e o desenvolvimentismo anacrônico.

Para Sachs (2002), a abordagem fundamentada na harmonizaçáo de objetivos sociais, ambientais e econômicos, primeiro chamado de ecodesenvolvimento ${ }^{12}$ e depois de desenvolvimento sustentável, não se alterou substancialmente nos vinte anos que separaram as conferências de Estocolmo e do Rio. Acredita que continuam válidas as recomendaçôes de objetivos específicos para oito de suas dimensōes: social, cultural, ecológica, ambiental, territorial, econômica, política nacional e política internacional.

Io Contra o argumento de Solow, Geogerscu-Roegen (1976, p. I6) explica que a ideia de substituição de recursos naturais por outros fatores revela uma visão equivocada do processo econômico, pois não há fatores materiais que não sejam recursos naturais.

II Em 1995, Grossman e Krueger publicaram um artigo no The Quarterly Journal of Economics, no qual examinam o comportamento da renda per capita e quatro tipos de indicadores de deterioração ambiental (poluição atmosférica urbana, oxigenaçáo de bacias hidrográficas, sua contaminação por metais pesados e rejeitos fecais). Concluíram que o crescimento econômico só prejudicaria o meio ambiente até determinado patamar de riqueza - que os autores acreditam ser em torno de oito mil dólares per capita - e, depois, passaria a melhorar a qualidade ambiental (VeIGA, op. cit.).

I2 O conceito foi lançado por Maurice Strong em I973 - primeiro diretor executivo da Unep e integrante da Comissão Brundtand -, mas foi Ignacy Sachs quem teorizou suas estratégias. 
Segundo essa ótica, a sustentabilidade ambiental estaria fundamentada no duplo imperativo ético de solidariedade sincrônica, com a geração atual, e de solidariedade diacrônica, com as geraçôes futuras, e impele a busca de soluçôes triplamente vencedoras (isto é, em termos sociais, econômicos e ecológicos), eliminando o crescimento selvagem obtido à custa de elevadas externalidades negativas (SACHS, op. cit.).

Como fica evidente na trajetória histórica da noção de desenvolvimento sustentável e por esta breve apresentaçáo de alguns dos diversos entendimentos sobre ela, o termo é muito usado, polissêmico e controverso. Nos diversos contextos em que é utilizado, representa e significa ideias distintas e, por vezes, contraditórias.

Nesse sentido, a questão da sustentabilidade pode ser vista como um objeto privilegiado de uma Sociologia do Conhecimento Científico da questáo ambiental que possa fornecer elementos conceituais para se pensar náo apenas acerca da questáo da sustentabilidade em si, mas também refletir sobre as fronteiras da política e da ciência, sobre os condicionantes sociais da produçáo do conhecimento científico em um contexto interdisciplinar e sobre a geração de controvérsias científicas e divergências políticas e teóricas, provenientes de tradições disciplinares, premissas teóricas, paradigmas e/ou visôes de mundo distintas.

\section{FONTES CONSULTADAS}

Acselrad, Henri. Conflitos ambientais no Brasil. Rio de Janeiro: Fundação Heinrich Böll, 2004.

BeCK, Ulrich. Risk society: towards a new modernity. London: SAGE Publications, I992.

BLoor, David. Knowledge and social imagery. London: Routledge \& Kegan Paul, 1976.

Bourdieu, Pierre. A economia das trocas simbólicas. São Paulo: Perspectiva, $200 I$.

Castoriadis, Cornelius. As encruzilhadas do labirinto. Rio de Janeiro: Paz e Terra, I997.

Diegues, Antônio Carlos. Desenvolvimento sustentável ou sociedades sustentáveis: da crítica dos modelos ao novo paradigma. São Paulo em Perspectiva, v. 6, n. I e 2, pp. 22-29, jan./jun. 1992.

Dryzer, J. The politics of the earth. Oxford: Oxford University Press, 2005.

EDINGER, Raphael; KaUl, Sanjay. Sustainability mobility: renewable energies for powering full cell vehicles. London: Praeger Publishers, 2003.

Ferreira, Leila da C. Ideias para uma sociologia da questão ambiental no Brasil. São Paulo: Annablume, 2006.

Ferreira, Leila da Costa (Org.) Teoria social, interdisciplinaridade e questão ambiental na América Latina. Campinas: Editora Unicamp, 2009 (no prelo). 
Georgescu-Roegen, Nicholas. Energy and economic myths: institutional and analytical economic essays. New York: Pergamon Press, 1976.

Georgescu-Roegen, Nicholas. The entropy law and the economic process. Cambridge: Harvard University Press, I995.

Giddens, Anthony. As consequências da modernidade. São Paulo: Unesp, I99I.

Grossman, Gene; Krueger, Alan B. "Economic Growth and the environment." The Quarterly Journal of Economics, I995. In: VeIGA, José Eli. Desenvolvimento sustentável-O desafio do século XXI. Rio de Janeiro: Editora Garamond, 2005.

Habermas, Jurgen. "Modernidade - Um projeto inacabado." In: Arantes, Otília; Arantes, Paulo Eduardo. Um ponto cego no projeto moderno de Jurgen Habermas: arquitetura e dimensão estética depois das vanguardas. São Paulo: Brasiliense, 1992.

Hannigan, John A. Sociologia ambiental. Petrópolis, Rio de Janeiro: Vozes, 2009.

Hoeffel, João. Abordagens para a sustentabilidade. Uma análise preliminar. In: Ferreira, Leila da Costa (Org.) Teoria social, interdisciplinaridade e questão ambiental na América Latina. Campinas: Editora Unicamp, 2009 (no prelo).

Kunn, Thomas S. As estruturas das revoluçóes cientificas. São Paulo: Perspectiva, 2007.

Lima, Gustavo. O debate da sustentabilidade na sociedade insustentável. Politica \& Trabalho, João Pessoa, v. I3, pp. 202-222, 1997.

Lima, Gustavo da C. O discurso da sustentabilidade e suas implicaçôes para a educação. Ambiente \& Sociedade, Campinas, v. 6, n. 2, jul.-dez, 2003.

Lyotard, Jean-François. O pós-moderno. Rio de Janeiro: José Olympio, I986.

Mannheim, Karl. Ideologia e utopia. Rio de Janeiro: Zahar Editores, I968.

Mulkay, Michael. Science and the Sociology of knowledge. London: G. Allen \& Unwin, I985.

Nobre, Marcos; Amazonas, Maurício (Org.) Desenvolvimento sustentável: a institucionalização de um conceito. Brasília: Editora Ibama, 2002.

PaeHlke, Robert. Environmentalism and the future of progressive politics. Yale: New Haven, I989.

SACHs, Ignacy. Caminhos para o desenvolvimento sustentável. Rio de Janeiro: Garamond, 2002.

VeIgA, José Eli. Desenvolvimento sustentável - O desafio do século XXI. Rio de Janeiro: Editora Garamond, 2005. 
Yearley, Steven. The green case: a Sociology of environmental issues, arguments and politics. London: Routledge, 1992.

Zhouri, Andréa; Laschefski, Klemens; Pereira, Doralice (Orgs.) A insustentável leveza da politica ambiental - desenvolvimento e conflitos socioambientais. Belo Horizonte: Autêntica, 2005. 